\title{
Surfing, sinking and swimming in the WTO
}

Experiences of student journalists covering SPICOL - the Student Pacific Island Conference of Leaders - at the University of the South Pacific Laucala campus on the future of the World Trade Organisation in the region.

\section{By PATRICK CRADDOCK}

SPICOL - the Student Pacific Conference of Leaders held first in 1996 at the University of the South Pacific in Fiji - was a week long simulation exercise based on a model of an international conference. It involved students from a number of courses around the university. All played dilferent roles, prime ministers, foreign ministers, advisers and leaders of pressure groups - churches, trade unions, women's rights activists, NGOs etc. Journalism students covered the conference and reported on it daily. The theme was "The Impact of The World Trade Organisation on the South Pacific in the 21st Century".

JOURNALISM in the South Pacific was developed from British and other European models. Each island country as it came under a colonial power, gradually gave birth to a small newspaper. In the case of an extremely small country this was a cyclostyled newsletter. The editor, reporters, photographers and typists may have been two or three people, usually expatriate or even one versatile person plus a local trainee.

The views the colonial editor hoped to develop in local staff were more often than not, based on a firm reading of the big papers of London and Paris. These hallowed journals arrived by sea several months after the day of publication. Their impact on local journalists was probably more in the manner of a metaphor than an example of how to write a strong news story. 
Small radio stations also showed a colonial face, but it was a public service face committed to news and information. That is changing. Their countenance is becoming that of the smiling dollar and with the growth of the free market philosophy more and more public service radio stations are becoming commercial ones. News and Current Affairs fits into smaller and smaller slots, and shows a tendency to focus on short news items, mini-sound bites and to talk about the quirky habits of famous Hollywood faces. It assumes we only love male contact sports that have a good sponsorship rating.

Television in the South Pacific has been around a long time, although not as long as in the more affluent Western nations. It too, is controlled by colonial patterns of thought. TV was at first seen as a tool for nationhood and development. But once the rhetoric was over the programming settled down to showing American and British sitcoms, crime and medical dramas, and sport.

In Fiji, TV first arrived via New Zealand as a method of bring World Cup Sevens Rugby to the population. Fiji now has a regular commercial TV service that seeks to pay its own way and make a profit.

In a recent presentation to journalism students at the University of the South Pacific, (Horn, 1997) notes that

...the advertisers are those with high volume sales, large supermarkets and intemational products like Coca Cola and Pepsi Cola which have very high advertising budgets. The target is the upper income and the upper educational level.

To put this in a wider economic context, the UNDP Fiji Poverty Report released at the end of 1996, reported that approximately one quarter of the nation were living in poverty and another quarter close to the poverty line. The proportion is still growing. Watching TV with its regular advertisements for cars and fast foods, and with its popular entertainrnent programming, it is hard to see that any poverty exists in Fiji.

Few of the small South Pacific islands have a country-wide TV service. Live transmission is still relayed to a few urban centres, and outlying rural populations wait for what is everyday fare for much of the Western world. While most South Pacific island communities have been independent of their colonial masters for at least two decades, the mind pattern of the former master is still at work, even if the face and the accent of the news readers is different.

Local politicians put pressure on the media to be a tame messenger of government. The media is frequently accused of bias. I give you a few examples.

In Fiji, it was the media who first found out about a bank scam running 


\section{PATRICK CRADDOCK}

to more than F\$200 million. There was an outcry from Members of Parliament and other political figures about leaked documents, dollar figure inaccuracies and ethics. Now, some two years later the police have lined up a number of eminent people for prosecution. This includes the former chief manager of the bank, various MPs and police officers.

$\square$ Two journalists were imprisoned in Tonga, for allegedly insulting the dignity of Parliament. The conflict was as much about class rights in Tonga as about the freedom of the press. They were later released as radio, TV and newspapers repeatedly asked uncomfortable questions to politicians and the spokespersons.

$\square$ In Samoa, the leader of the opposition was banned from public radio through the direct intervention of the Prime Minister.

A newspaper editor in the Federated States of Micronesia, faced pressure and had her work permit revoked. She was accused of refusing to consider local cultural concerns when developing news.

$\square$ At the time of writing this paper, the Ombudsman in Vanuatu is facing a court battle with Parliament which is trying to dismiss her. This year she was awarded the highest South Pacific news honour, The Freedom of Information award, in recognition of her efforts in publicising information relating to alleged misconduct by Government officials.

Journalists will read their own interpretations into these political decisions.

Colonial history helped to both change and also reinforce authoritarian and hierarchical patterns of power in South Pacific island countries. The development of quality journalism is a difflcult and sometimes a painful way, to make a living if you also wish to live in peace and harmony with political masters.

One incident typifies the cultural pressures in the life of a journalist. A student journalist (Sen, 1997) working at the local TV newsroom reported being assigned in TV news crew sent to cover a demonstration in support of a Government minister, who was also a high chief in Fiji and linked to an investigation into a passport scandal. One member of the crew, the cameraman, refused to shoot the story on video tape as the minister concerned was from his own high chief land-owning group. To have approached her would have contravened social taboo and tribal obligations. The television audience was seen as secondary to the primary role of social obligation. The story did not end there. Journalists followed other angles although the Minister and the Ministry of Fijian Affairs refused to comment; until the matter was discussed in Parliament and eventually resolved by the justice system.

82 PACIFIC JOURNALISM REVIEW 5:1 1999 


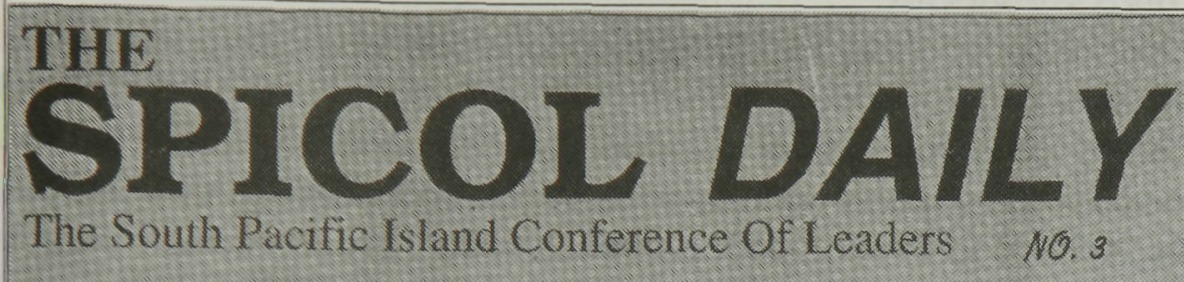

\section{What's on tonight}

Monday, 20 Octater, 19y?

\section{$7.00 p m$}

Speech by the Honourable Chairperson, Ahohiva Levi.

\section{$7.20 \mathrm{pm}$}

COMMUNIQLE read by the Rapporteur Vivian Koster.

\section{$7.35 p m$}

Official signing of the COMMUNIQUE by country leaders

\section{$7.45 \mathrm{pm}$}

Speeches and presentation of certificates

\section{$8.20 \mathrm{pm}$}

Buffet Dinner \& Fntertainment

For more on
SPlCOL:
Tune in to FM88.8
at 1 pm
tommorrow with
Ken Erowm and
his team

\section{Chair Limits Discussions More participation wanted from leaders}

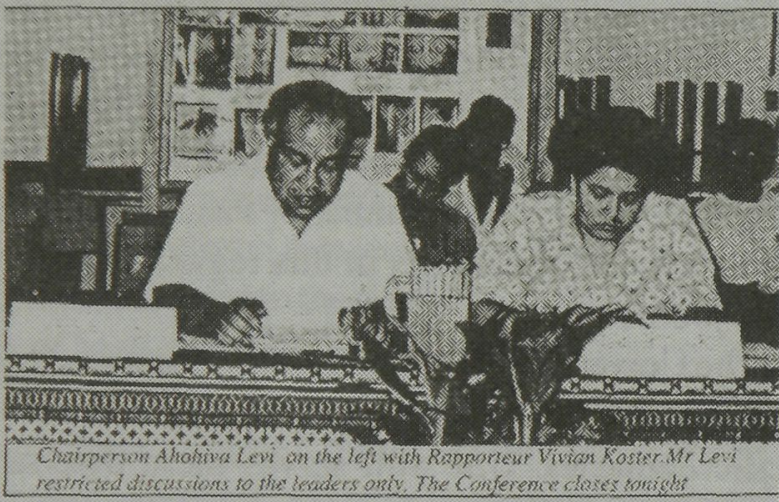

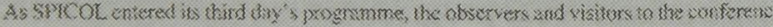

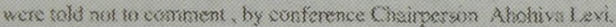

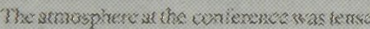

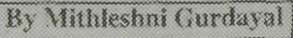

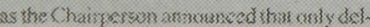

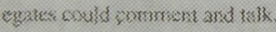

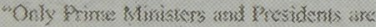

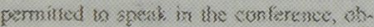

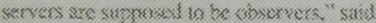

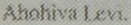

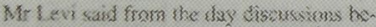

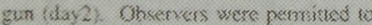
cxmm carme sumflicis.

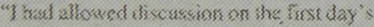

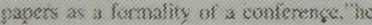

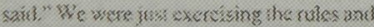

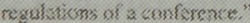

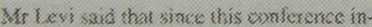

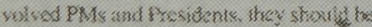

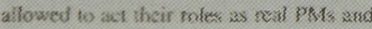
Presidents in a nent conf essanes.

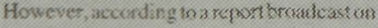

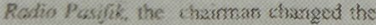

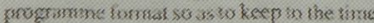
seticulate:

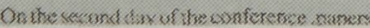

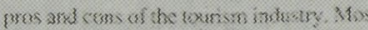

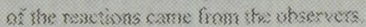

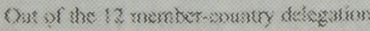

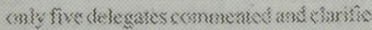
nut the isturas nisens.

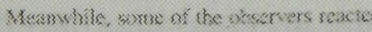

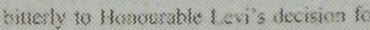

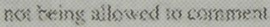

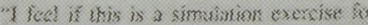

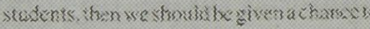

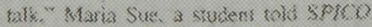
DaILX.

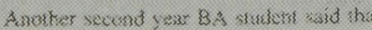

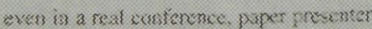

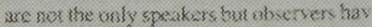

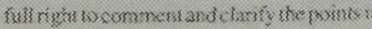
รAl

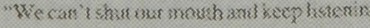

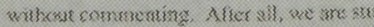
senust'l" ke sisik

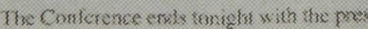

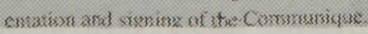

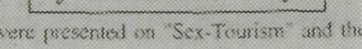

The SPICOL Daily: Newsletter from the 1997 conference. 


\section{PATRICK CRADDOCK}

Journalism students of USP trying to obtain news stories face a real dilemma as they try to explore stories that will reflect views other than those desired by many government ministers, church leaders, high chiefs and those individuals who classify themselves as untouchables through their use of the terms "cultural sensitivity" and "status immunity". In a recent radio interview (Meadows, 1997) a senior lecturer in journalism at Griffith University in Australia, spoke of cultural attitudes that inhibit normal television interviewing with indigenous Australians. He said a difficulty for aboriginal journalists in Australia was that of physically approaching certain people who were elders in their community. Getting close to them by camera was seen as offensive. A "medium-shot" on camera was acceptable, a "close-up" shot was not.

How this will change, I don't know as the scenario I have outlined on class and culture applies to a number of Pacific countries. But I do know that it is a task that future journalists in this region must face honestly or they become lesser journalists.

The University of the South Pacific, with its main campus in Suva, Fiji, also grew out of a colonial wish to establish a university to serve 12 small South Pacific countries. USP still serves these diverse groups of nations. It now teaches a three-year programme in journalism which is part of a BA degree, and a two-year diploma in Pacific Journalism. These courses, funded by the French Government, attract young men and women students from a number of the USP regional countries and is training them to be print, radio and TV journalists. They study print, radio, graphics, photography and television.

Their BA is supplemented by other courses, so that an aspiring magazine writer in economics may take a paper in that subject with the hope that there will soon be a spare job for a Pacific-based specialist freelance writer on The Economist on the morning of the year 2000. Technical facilities at the USP are excellent. In my own area of radio broadcasting, I have a studio set up to international standards and can record, edit and produce interviews and radio documentaries on both analog and digital equipment.

The real difficulty in training is in influencing these young students to deal with real cultural pressures and to work under genuine journalism pressures. The Student Pacific Island Conference of Leaders (SPICOL) ably served both needs. This was a model conference, a large simulation exercise, that lasted an academic week. It brought together students from the 12 South Pacific countries with the purpose of examining the impact of the World Trade Organisation on the South Pacific in the next century. Students played the parts of prime 84 PACIFIC JOURNALISM REVIEW 5:1 1999 
ministers and foreign ministers. Each had one or two political advisers, who were also students. Third year students studying politics and economics, prepared country position papers and supplied them to the politicians for delivery at the conference.

\section{SPICOL methodology:}

SPICOL got off to a grand start and closely followed the format of many international conferences. There was a formal opening, with the Vice-Chancellor, welcome speeches and a large feast. It was a huge success. Next morning the political side of the conference began. Each country leader presented the views and concerns of their country. Guest speakers representing academic experts presented research papers on the implications of joining the WTO. There were discussions based on the papers and many points of view were expressed. One conference day was a closed session during which a conference communiqué was drafted. It was presented to the conference the following day. SPICOL closed after a week of hectic activity. It left behind students who were excited and in some cases bewildered.

In the case of the journalism students, SPICOL left them wiser and extremely tired. Each day of the conference, students were there to report about SPICOL in print and photography, radio and TV. As all three areas of the media had to be covered the numbers of students for each group was small. The journalism students said that the number of hours they had to attend the conference were far greater than they expected, especially as some of the conference sessions were in the evenings and overran time deadlines set by the SPICOL organizers.

A major problem faced by each of the journalism media groups was what aspects of SPICOL they should cover. Each evening it was necessary to prepare small newspaper, TV and radio items. There had been no problem with reporting the opening event. It was self evident that the speech from the guest speaker, the Vice-Chancellor of USP, would be given ample news coverage. There was a group photograph of all the participants taken under the banner announcing the opening of SPICOL. The opening feast had not only food, it also had a troupe of dancers. The editor and the production team for the newspaper reported the speech, feast and the dancers. The first edition of the newspaper showed the group photograph, a picture of the SPICOL cake and close-ups of the dancers. Fiji radio, TV and the press reported the same event.

Day two and three were very different as the conference moved into action.

PACIFIC JOURNALISM REVIEW 5:1 $1998 \mathbf{8 5}$ 


\section{PATRICK CRADDOCK}

Politicians and guest speakers gave speech after speech in rapid succession. There were many discussions where conflicting views and interpretations surfaced with politicians, their advisers and the various pressure groups who gave papers at the conference. Students began to realise that the conference was moving at a faster pace than they had anticipated and there was an increasing number of viewpoints being presented. They had to quickly decide the topic they should focus on for their news reports. Even more quickly, they had to decide if they would select a person to interview, and then more quickly still, they had to write about the events of that day. It was a time of shock. These student journalists had never before had the opportunity to report on such a huge gathering of "eminent leaders" with so many worthwhile papers being presented by Government officials, academics and interest groups representing women, trade unions, NGOs, enviromentalists and the church.

I spent hours talking with students who found themselves in a dilemma as they wondered which of the many speeches they should cover, and from which country. They asked questions about how much they edit out and how much to leave in, and which part to focus upon? One student summed up her problem by saying there was "too much content being presented at SPICOL". She felt confused and said she could not fairly represent all the views being expressed.

Another said he could not write any shorthand, nor could he accurately put down in his notebook the many points being made in the presentations. He was afraid of misrepresenting the views contained in the prime minister's speech. Another said she wanted to interview one of the ministers, but did not know how to do it or to focus her questions, as the minister had spoken on a number of themes affecting his country. She could not decide which theme was the most interesting and how she would condense the many views into a short news item. These are real life questions for a journalist.

These young people had previously conducted a number of interviews, but they had executed this work under controlled conditions. For example, an assignment due on a set date, would be set on a suitable topic. A person would then be identified as the potential interviewee. The trainee would then talk over the interview topic with the lecturer and devise a question format. Next came the interview. After that there was always time to see their journalism tutor about the writing, editing and the polishing of the material for presentation. In short, life was simpler for the student. They had a clear timetable to follow, a specific topic and one interviewee only. SPICOL, in comparison, was a monster with tentacles of information spreading in many directions at any one time.

86- PACIFIC JOURNALISM REVIEW 5:1 1999 


\section{Ethical dilemmas:}

There was also one significant event which would have brought a sense of deja $v u$ to many news editors. A student reporter wrote an article in the daily SPICOL newspaper criticising a statement by the Prime Minister of Samoa, and there also a critical comment on the Prime Minister of the host country, Fiji. It quickly became a cause célèbre as the mini newspaper was released for public consumption. The prime ministers were angry. Other SPICOL politicians supported them. There was even a suggestion that the media be banned from further attendance at the conference. Wiser voices prevailed and the media remained. But the chairperson was asked to seek a written apology from the newspaper. This was another dilemma for the young editor. Once again there was a fervent meeting with the lecturing staff.

Media ethics became an important issue that had to be determined and promptly resolved. By the end of that day a decision had been made, and the editor had clearly worked out in his mind why the article had been written and printed. He decided that there was to be no apology. In my opinion the editor would have quickly written an apology if he had not been given an opportunity to sit down quietly with his lecturers and be asked as to why the article was written in the first place. A radio interview was later conducted with one of the offended prime ministers. He referred to the need for journalists to show respect for authority, but failed to comment on free speech, nor did he seem to appreciate the right of the public to have access to differing viewpoints.

\section{Gender roles:}

Gender roles within the conference were of some significance. Two young women journalists were told by "a government representative" that after they had written their stories, their reports should be checked with the officials. Neither did so, but it is noticeable that an informal survey with some of the male journalists revealed that nothing had been said to them about having press stories checked out by officialdom. Another example of discrimination during the conference involved the Chairperson, who was a woman. She was accused by three participants of favoring both her own island ethnic group and women in the conference.

Before the SPICOL conference began, it was necessary to gather as much information as possible on the role of the WTO. Much of this work was accomplished by one student with a background of practical journalism gained 


\section{PATRICK CRADDOCK}

by working for the press and TV. She was also a politics student and presented three research papers at the conference. After looking at the information available in the USP library and outside libraries, it became clear that there was little information on the WTO and a scarcity of any data relating to the South Pacific region.

\section{The Internet:}

The Internet became the main source of research activity as the WTO had a web page. There was its history, its legal structure and its dispute procedures. This was used as "fill in" material by the radio commentators before and during gaps in the official presentations of papers. While there was an abundance of information on the WTO including their latest press releases, it soon became clear that there was little data on the 12 island nations in this part of the world. Invariably the word "Pacific" included the large countries that form the rim of Asia. There was no significant data relating to the small South Pacific countries that constitute our political region. After ten hours of Internet browsing the task was abandoned. But important data on the role of the WTO had been collected.

\section{Conclusion:}

The SPICOL conference ended with a round of speeches and a bland communiqué. But what of the learning that eventuated from SPICOL? Let me put it briefly into two sections. The immediate lessons and a set of recommendations that came from a focus group discussion.

For the young student journalists there was the experience of media coverage of a large event that took place over several days. This sustained activity is not normally available to student joumalists who usually work on a single assignment or sporadic news articles for students journals. In the udse of SPICOL they were working on stories that were breaking hour by hour. In addition there were many speeches and presentations being given in a single day. Students had to decide which stories to select and to choose an angle of focus of presentation for their reports. There was the dilemma about how the views of all the 12 countries could be represented. A question of being fair and impartial.

Many journalism students worked hard, a few were lazy. As with committees the hard workers carried the rest. Professional technical equipment broke down. The laser scanner to scan the photographs failed on day one. For the rest of the conference the photographs for the newspapers were cut and pasted by 88 PACIFIC JOURNALISM REVIEW 5:1 1999 
SPICOL

hand, instead of being electronically transferred. The TV crew filled many hours of video tape recording speeches and then showed considerable uncertainty when faced with editing this vast amount of recorded tape to put together a short news bulletin. Print journalists were quicker at selecting a focal point for their stories. All students found the deadlines to be daunting at the beginning of the conference. By the end of the week, they were becoming efficient at working out their time limitations and how much time they required to prepare their news stories.

Lessons were learned for future exercises. One of the politicians spoke about his problem at dealing with the many journalists who kept approaching him at inconvenient times when he was busy. He also complained about the number of journalists who approached him about the same speech and at different times. This is a valid concern. In the real world politicians and celebrity figures have their own public relations or press officers to organise briefings for journalists covering a conference. Future exercises of this nature should include a number of press officers with these positions being taken by senior journalism students. It will give them the opportunity to see how the media puts pressure on politicians and to give them training in media "guard dog behavior".

From my point of view as a lecturer for the journalism program, I also saw SPICOL as a lesson in helping students gain a maturity in asking questions. The South Pacific region has strong hierarchies of authorities at the family, the community and the political level. It can be an intimidating task for students to ask their leaders searching questions on their political policies. Through this simulation exercise, journalism students learned to speak freely and interview other students who were playing the roles of political leaders. When they leave the university with their degrees and begin work in the media, the effects of this unique SPICOL simulation exercise will surely begin to translate into real life. These students will become journalists who will have learned to research, ask meaningful questions on an important topic and to write their articles within deadlines. The politicians of the South Pacific will surely become publicly more accountable through improved and accurate media coverage of their activities.

\section{References:}

Cass, Phillip (1995), "Dilemma for Fiji Media and the Constitution", Pacific Journalism Review, November, University of Papua New Guinea, Port Moresby, Papua New Guinea. 